Ankara Üniversitesi Eğitim Bilimleri Fakültesi Dergisi

Yll: 2021, Cilt: 54, Sayl: 2, 361-389

DOI: 10.30964/auebfd.683683, E-ISSN: 2458-8342, P-ISSN: 1301-3718

\title{
Üniversite Öğrencilerinde İlişkisel Saldırganlık: Karanlık Üçlü Kişilik Özelliklerinin Rolü'
}

\begin{tabular}{cccc}
\hline MAKALE TÜRÜ & Başvuru Tarihi & Kabul Tarihi & Yayım Tarihi \\
Araştırma Makalesi & 03.02 .2020 & 06.02 .2021 & 19.04 .2021 \\
\hline \multicolumn{4}{c}{ Nesrin Karaaslan } \\
\\
Milli Eğ 2 &
\end{tabular}

Cem Ali Gizir (iD ${ }^{3}$

Mersin Üniversitesi

Öz

$\mathrm{Bu}$ çalışmanın amacı, Karanlık Üçlü (Makyavelizm, narsisizm ve psikopati) kişilik özelliklerinin üniversite öğrencilerinin ilişkisel saldırganlık (dışlama, manipülasyon, dedikodu) düzeylerini yordayıp yordamadıklarını incelemektir. Araştırma grubunu, 2018-2019 öğretim yılında, bir kamu üniversitesinde öğrenimlerine devam eden 725 (457 kadın, 268 erkek) lisans öğrencisi oluşturmaktadır. Araştırma kapsamında "Kişisel Bilgi Formu", "Arkadaşlık İlişkilerinde İlişkisel Saldırganlık Ölçeği” ve "Karanlık Üçlü Ölçeği” kullanılmıştır. Verilerin analizinde çoklu regresyon analizinden yararlanılmıştır. Araştırma bulguları, Makyavelizm ve psikopati kişilik özelliklerinin üniversite öğrencilerinin ilişkisel saldırganlık düzeylerini anlamlı ve düşük düzeyde yordadıklarını göstermiştir. Benzer şekilde Makyavelizm ve psikopati kişilik özellikleri, ilişkisel saldırganlığın alt-boyutları arasında yer alan dışlama eğilimini düşük düzeyde yordamaktadır. Diğer yandan üniversite öğrencilerinin arkadaşlık ilişkilerindeki manipülasyon eğilimlerini sadece Makyevalizm yordarken dedikodu eğilimlerini ise sadece psikopati yordamaktadır. Narsisizm kişilik özelliğinin ise ilişkisel saldırganlık ve altboyutlarının anlamlı bir yordayıcısı olmadığı belirlenmiştir. Araştırma bulguları alanyazın odağında tartışılmış, gelecekteki uygulama ve çalışmalara yönelik öneriler sunulmuştur.

Anahtar sözcükler: İlişkisel saldırganlık, karanlık üçlü, Makyavelizm, narsisizm, psikopati, üniversite öğrencileri.

Etik Kurul Kararı: Bu araştırma, 01.01.2020 tarihinden önce yapıldı̆̆ı için etik kurul kararı zorunluluğu taşımamaktadır.

${ }^{1} \mathrm{Bu}$ çalışma, Mersin Üniversitesi Eğitim Bilimleri Enstitüsünde Temmuz 2019 tarihinde tamamlanan ve birinci yazarın ikinci yazar danışmanlığında gerçekleştirdiği yüksek lisans tez çalışmasının bir bölümüdür ${ }^{2}$ Uzman Psikolojik Danışman, Milli Eğitim Bakanlığı, e-posta: nesrin-karaaslan2015@hotmail.com, https://orcid.org/0000-0002-3896-9699

${ }^{3}$ Sorumlu Yazar: Prof. Dr., Eğitim Fakültesi, Eğitim Bilimleri Bölümü, Rehberlik ve Psikolojik Danışmanlık Anabilim Dalı, e-posta: cagizir@mersin.edu.tr, https://orcid.org/ 0000-0002-1928-781X 
Bireylerin yaşamlarını devam ettirebilmeleri için belirli gereksinimleri vardır. $\mathrm{Bu}$ temel gereksinimlerden biri de belirli bir sosyal çevreye ait olmadır. Sosyal bir çevreye ait olma gereksinimini sağlayan en önemli öğelerden biri ise arkadaşlık ilişkileridir. Bir başka deyişle doğası gereği sosyal varlıklar olarak nitelendirilen bireylerin çevrelerinde sosyal ilişkiler kurması oldukça olağandır. Bireyler, dinlenilmek, anlaşılmak, kendini ifade etmek ve duygularını paylaşmak adına başkalarına gereksinim duymaktadırlar. Bu gereksinimleri karşılamak adına kurulan arkadaşlık ilişkileri sayesinde bireyler, özgüven, kendi içsel dünyalarında anlaşılma ve kendilerini anlama gibi çok çeşitli kazanımlar elde etmektedirler (Demir, GörgünBaran ve Ulusoy, 2005).

$\mathrm{Bu}$ bakış açısıyla ele alındığında her birey, içinde bulunduğu çevredeki çeşitli sosyal gruplara uyum sağlamak zorundadır. Bu uyum sürecinin sağlıklı bir şekilde gerçekleştirilmesinde grup içindeki bireylerin tutum ve davranışları büyük önem taşımaktadır. Bireyler, sosyal ilişkilerinde çoğunlukla olumlu davranışlar sergilemekle birlikte, sosyal gruplar içinde zaman zaman olumsuz tutum ve davranışlarda da bulunabilmektedirler. Sözü edilen olumsuz davranışlardan bazıları ise dedikodu yapmak, diğerleri hakkında söylenti çıkarmak ya da birilerini dışlamak gibi grup üyelerine zarar verme amacı içeren davranışlar olarak betimlenmekte ve ilişkisel saldırganlık olarak tanımlanmaktadır (Crick ve Grotpeter, 1995).

Başka bir deyişle ilişkisel saldırganlık, amaçlı, kişilerarası manipülasyon (hileli yönlendirme) ya da sosyal dişlama yoluyla mağdurun sosyal statüsüne ya da sosyal ilişkilerine zarar vermeyi hedefleyen bir davranış biçimidir (Archer ve Coyne, 2005). Mağdurların kişilerarası ilişkilerini hedef alan ilişskisel saldırganlık davranışları, ilişkilerin sürdürülmesi için bir araç olarak da görülebilmektedir. Dolayısıyla ilişkisel saldırganlık, riske atılmak ya da incitilmek istenen bireylerin topluma aidiyet gereksinimlerine darbe vurmak amacıyla genellikle sosyal ilişkiler yoluyla yapıldığından, bireylerin sosyal uyumları açısından tehlike oluşturmaktadır (Kurtyılmaz, 2011). Bu yönüyle ilişkisel saldırganlık, bireylerin arkadaş çevresine ve romantik ilişkilerine zarar vermekte, sosyal ortamda başkalarının birey ile ilgili izlenimlerinin olumsuz yönde değişmesine ve bireyin toplumdan dişlanmasına neden olmaktadır (Linder, Crick ve Collins, 2002). Bu tanımlamalar 1şı̆̆ında, ilişkisel saldırganlığı diğer saldırganlık türlerinden farklı kılan en önemli nokta, ilişskisel saldırganlığın sosyal ilişkileri kontrol altında tutmayı ve bu ilişkilere zarar vermeyi amaçlamasıdır (Crick ve Grotpeter, 1995). Bu yönüyle ilişkisel saldırganlık, başkaları arasında daha az dikkat edilen bir saldırganlık türü olarak düşünülmekte ve diğer saldırganlık türlerine göre daha fazla tercih edilebilmektedir.

İlişkisel saldırganlık odağında sıklıkla ele alınan davranış örüntülerinden biri dışlamadır. Dışlama davranışları, bireyleri grup içinde yok sayma, onları görmezden gelme, diğer grup üyeleri ile görüşmeyi engelleme ya da grup etkileşiminden yoksun bırakma şeklinde görülebilmektedir (Abayhan, 2013). Abrams, Hogg ve Marques'a göre (2004) güvenlik ve aidiyet gereksinimlerinin başkaları tarafından tehdit edildiği düşünüldüğünde bireyler, bu tehdidi ortadan kaldırılmak için diğerlerini dışlama 
davranışları gösterebilmektedirler. Bu durum, dışlanmış bireylerde tükenmişlik, depresyon, yalnızlık, düşük özgüven ve özsaygı gibi sorunlara yol açmaktadır. Bu şekilde dışlama davranışını gerçekleştiren bireyler, hoşlanmadıkları bireylere doğrudan veremedikleri zararları vermiş ve amaçlarına ulaşmış olurlar (Williams, 2009). Buna bağlı olarak dışlamayı gerçekleştiren kişi dikkat çekmediğini ve toplum içinde kendine yönelik algının zedelenmeyeceğini düşündüğünden, rahatlıkla bu davranışlarına devam edebilir (Abayhan, 2013).

Bir diğer ilişkisel saldırganlık davranışı olarak değerlendirilen ve bireylerin kendi amaçları doğrultusunda, diğer bireyleri yönlendirmesi ya da yanıltması (Austin, Farrelly, Black ve Moore, 2007) olarak betimlenen manipülasyon, bireylerin içinde bulundukları sosyal ortamlarda kendi kişisel çıkarları için olayları ve kişileri yanıltmak, değiştirmek ve yönlendirmek için yapılan taktiksel davranışlar (sevimli görünme, yok sayma, baskı yapma, çeşitli nedenler sunma ve çocukça davranışlar sergileme vb.) olarak tanımlanmaktadır (Buss, Gomes, Higgins ve Lauterbach, 1987). Wilkinson'a göre (2012) manipülasyon, bireylerin düşüncelerini, onlara hissettirmeden değiştirmeye odaklıdır. İkincisi, manipülasyonda kasıtllık vardır ve sergilenen davranışlar, bilinçli ve art niyetli olarak yapılmakta ve zorlama içermektedir. Son olarak, manipülatif davranışlarda bulunan bireyler için kendi kişisel çıkarları her zaman ön plandadır ve bu durum diğerlerinin söz haklarını elinden almayı ve özerkliğine müdahale etmeyi kapsamaktadır. Bu noktada, manipülatif davranışlar içinde olan bireylerin amaçları doğrultusunda çevrelerindeki bireylerin davranışlarına göre hareket ettikleri, onları sürekli kontrol etmeleri dolayısıyla kendi duygularını dışa vurmada dikkatli davrandıkları belirtilmekte ve bireylerin kendi amaçları doğrultusunda başkalarını yönlendirme eğilimi içinde olmakla birlikte, bireyleri değiştirme, kısıtlama davranışları sergiledikleri vurgulanmaktadır (Wastell ve Booth, 2003).

İlişkisel saldırganlık davranışları içinde yer alan dedikodu ise bireyler tarafından kötü niyetle yapılan, diğer bireyleri olumsuz etkilemek amacıyla manipüle etmeyi içeren ve başkalarını kötü göstermek, dışlamak için uğraşılan, davranışlar olarak belirtilmektedir (Baumeister, Kathleen ve Vohs, 2004; Beersma ve Van Kleef, 2012; Dunbar, 2004; Solmaz, 2006). Benzer şekilde dedikodu, bireylerde zarar verme amacı içeren, toplumda sıklıkla görülen ve sosyal ortamlarda bilgilerin gerçekdışı olarak aktarılması ile bireylerin ortamda bulunmayan üçüncü kişiler hakkında konuşması olarak tanımlanmaktadır (Foster, 2004; Mills, 2010; Wu, Kwan, Wu ve Ma, 2018). Dedikoduda amaç, dedikoduyu başlatan bireyin zarar vermek istediği birey hakkında toplum içinde olumsuz bir algı oluşturmak veya sosyal grup içinde dışlanmasını sağlamaktır (Baumeister ve diğ., 2004). Bu süreçte, özellikle hoşlanılmayan kişiler ile ilgili gizli bilgiler bir araç olarak kullanılabilmekte ve dedikodu yapan bireyler kişisel amaçlarına ulaşmak için başkaları ile ilgili olumsuz konuşmaktan çekinmemektedirler (McAndrew ve Milenkovic, 2002). Genel olarak dedikodu yapmanın nedenleri ise diğer bireyler hakkında bilgi toplamak, içinde bulunulan grubu korumak, zevk almak, başkalarını kötü göstererek onlar ile ilgili olumsuz etki bırakmak olarak gösterilmektedir (Beersma ve Van Kleef, 2012; Hartung, Krohn ve Pirschtat, 2019). 
Dedikodu yapmanın olumsuz olarak algılanmasına karşın sıkça başvurulan bir davranış olduğunu belirten Ellwardt, Labianca ve Wittek'e göre (2012) dedikoduya başvuran bireyler, grup içinde sosyal statülerini yükseltmek, saygınlık kazanmak ve popüler olmak amacıyla dedikodu yapmada istekli olmaktadırlar. Dolayısıyla hem gruplarda kalıcı olmak amaçlanmakta hem de bir gruba ait olma gereksinimi karşılanmaktadır. Başka bir çalışmada ise dedikodu yapmanın nedenleri olarak kendini diğer bireylere göre güçsüz hissetmek, gruplarda yer edinebilmek ve rahatsız olunan kişiyi kıskanmak gösterilmektedir (Wert ve Salovey, 2004).

İlişkisel saldırganlıkla ilişkili etkenlerden biri olarak değerlendirilen kişilik özellikleri (Czar, Dahlen, Bullock ve Nicholson, 2010; Knight ve diğ., 2018; Schmeelk, Sylvers ve Lilienfeld, 2008), kişilik temelinde ele alınan en önemli kavramlardan biridir. Kişilik özellikleri, bireyleri tanımlayan, onları birbirinden ayıran ve bireyler hakkında bir bakış açısının kazanılmasını sağlayan etkenlerdir (Eryllmaz ve Ercan, 2011). Bu yönüyle kişilik özellikleri, bireylerin toplum içindeki ve dışındaki tutum ve davranışlarını açıklama noktasında oldukça önemli görülmektedir (Polatcı, Irk, Gültekin ve Sobacı, 2017). Bu noktada, Büyük Beşli[Big Five] (Goldberg, 1990), HEXACO (Ashton ve Lee, 2001) ve Karanlık Üçlü (Paulhus ve Williams, 2002) gibi tanımlamalar üzerinden temel kişilik özelliklerinin belirlenebilmesi amacıyla geliştirilen kavramların çeşitli çalışmalarda yaygın olarak kullanıldığı gözlemlenmektedir.

Olumsuz kişilik özellikleri arasında gösterilen ve Makyavelizm, subklinik (klinik düzeyde olmayan) narsisizm ve subklinik psikopati olarak betimlenen üç temel kişilik özelliğini içeren Karanlık Üçlü, sosyal ilişkilerin olumlu olarak sonuçlanmasına engel olan ve bireylerin sosyal ilişkileri kendi çıkarları için kullanmasına olanak sunan kişilik özellikleri olarak gösterilmektedir (Paulhus ve Williams 2002). Birbirinden farklı özellikler içermekle birlikte tek bir ortak kavram altında bir araya getirilen bu üç kişilik özelliğinin ortak yönleri "bencillik, insan ilişkilerinin yüzeysel, çıkar odaklı olması, uyumsuzluk, manipülasyona başvurma ve amaç odaklılık" (Özsoy ve Ardıç, 2017, s. 393) olarak sıralanmaktadır. Bu özelliklere ek olarak, Karanlık Üçlü özelliklerini sergileyen bireylerde yükselme hırsı, duygusal kopukluk, ilişkilerde soğuk davranma ve saldırgan davranışlar gösterme eğiliminin olduğu vurgulanmaktadır (Paulhus ve Williams, 2002).

Karanlık Üçlü kişilik özelliklerinden biri olan Makyavelizm, Niccolo Machiavelli tarafindan 1513 yılında yayınlanan Prens adlı kitabın ana teması kapsamında, ahlak ilkelerinin amaçlardan sonra geldiği, amacı gerçekleştirmek için ahlak kurallarının çiğnenmesinde tereddüt yaşanmayabileceği ya da çok kolay gözden çıkarılabileceği şeklinde belirtilmektedir (O’boyle, Forsyth, Banks ve Mcdaniel, 2012). Psikoloji alanına Makyavelizmi bir kişilik özelliği olarak kazandıran kişiler ise Christie ve Geis (1970) olmuştur. Makyavelist özelliklere sahip bireyler, kendi amaçları doğrultusunda her şeyin yapılabileceği kanısında olmakla birlikte, diğer bireylerin saf ve deneyimsiz olduklarına, çok kolay kandırılabileceklerine inandıkları için onları, kendi amaçları doğrultusunda yönlendirmekte herhangi bir endişe 
duymamaktadırlar (Toplu-Yaşlığlu ve Atılgan, 2018). Bu noktada, Makyavelist bireylerin elde etmek istedikleri amaçlar için mantıklı nedenler bulma çabalarına dikkat çeken O'boyle ve diğ. (2012), bu bireylerin amaçları doğrultusunda doğruları söylememeye, olayları çarpıtmaya, bireyleri kandırmaya, oyunlar çevirmeye ve diğerlerini kendi amaçlarını gerçekleştirmek için yönlendirmeye yatkın olduklarını belirtmektedirler. Bu kişiler, kendilerini çok belli etmemeye, olaylarda baskın olmamaya dikkat ederler. Ancak sayılan bu özelliklerin hemen hemen tüm bireylerde belli ölçülerde görülebileceği düşünüldüğünde, Makyavelist bireylerin bu tür davranışları amaçlı, sürekli ve tekrarlı olarak yaptıkları belirtilmektedir (Özsoy ve Ardıç, 2017). Bununla birlikte popüler olmayan bireyler, sosyal olma gücünü, popülerliği sayesinde elde edemedikleri için farklı yollar deneme gereği duyup bu yönde hareket etme eğilimi göstermektedirler (LaFontana ve Cillessen, 2002). Ayrıca ilişkisel saldırganlığı tercih eden bireyler, fiziksel saldırganlığ tercih edenlere göre daha fazla Makyavelist davranışlar sergilemektedirler (Peeters, Cillessen ve Scholte, 2010).

Karanlık Üçlü kişilik özelliklerinden bir diğeri olan narsisizm, kendinde olmayan bazı özelliklerin ya da psikolojik gereksinimlerin yoksunluğunun bilinçaltına itilmesi, kişinin kendi kendine var ettiği aşırı büyütülmüş benlik olarak açıklanmaktadır (Özsoy ve Ardıç, 2017). Narsisizmde, fiziksel bir temastan çok sözle başkalarına zarar verme ve onları incitme davranışları görülmektedir (Jonason, Richardson ve Potter, 2015). Narsisizm eğilimi yüksek olan bireyler, kendi özelliklerini aşırı beğenmekte, kendilerini fazlaca önemsemekte, göz önünde olmayı çokça arzulamakta, başkalarının fiziksel ya da psikolojik durumlarını önemsememekte ve diğerlerinin sadece onlarla ilgilenmesi gerektiğini düşünmektedirler (Toplu-Yaşlıoğlu ve Atılgan, 2018). Bu yüzden narsist bireyler, en çok değeri kendine veren, kendinden başkasını önemsemeyen, kontrolü elinde tutmaya çalışan, diğerlerini öznel çıkarları doğrultusunda yönlendiren ve statüye oldukça önem veren kişiler olarak görülmektedirler (Özsoy ve Ardıç, 2017). Bununla birlikte narsist bireyler, yüksek benlik algıları nedeniyle kendilerine gelebilecek eleştirileri bir tehdit olarak algılama eğilimindedirler (Aydın ve Akgün, 2014) ve bu yüzden eleştiriler karşısında saldırgan tutumlar sergileme olasılıkları yüksektir (García, 2009).

Son Karanlık Üçlü kişilik özelliği olan psikopati ise Cleckley'in (1941; akt. Sumner, 1942) The Musk of the Sanity adlı eserinde sorumsuzluk, ahlaki değerlerde yoksunluk, patolojik benmerkezcilik, utanç ve şükretme yoksunluğu, mantıksızlık, içgörü eksikliği, yalancılık ve güvensizlik davranışlarını temelinde tanımlanmaktadır. Ayrıca psikopati, birincil ve ikincil psikopati olarak iki alt grupta ele alınmaktadır. Birincil psikopatide, empati eksikliği, manipülasyon, suçluluk duymama, pişmanlık hissetmeme, kaygı duymama ve yüzeysellik davranışları yer alırken ve ikincil psikopatide dürtüsellik ve antisosyal davranışlar görülmektedir (Grieve ve Mahar, 2010; Newman, MacCoon, Vaughn ve Sadeh, 2005). Bu çalışmanın konusu olan subklinik psikopati ise genellikle birincil psikopati ile ilişkilendirilmekte ve empati yoksunluğu, düşük kaygı, heyecan arayışı, kendini kontrol edememe davranışları ile 
nitelendirilmektedir (Paulhus ve Williams, 2002; Ashton ve diğ., 2018). Ayrıca psikopati eğilimi yüksek olan bireyler, elde edilmek istedikleri amacın büyüklüğü ya da küçüklüğü önemsenmeyen, sadece bir şeyler elde etme amaciyla tehlikeli işlere kalkışan, sosyal yaşamlarında amaçsız ve plansız hareket eden ve arkadaşlık kurulmak istenilmeyen bireyler olarak tanımlanmaktadırlar (Erdoğan, 2018).

Üniversite yıllarında kurulan arkadaşlık ilişkilerinin, farklı bir sosyal ortam içinde bulunan genç-yetişkinlerin bilişsel, sosyal ve duygusal gelişimlerine olumlu katkı sağladığı belirtilmektedir (Astin, 1993). Başka bir deyişle sosyal çevrenin (özellikle yakın ilişkilerin), gelişimsel görevlerin sorunsuz bir şekilde tamamlanmasında olumlu katkısının olduğu ve bireylerde bilişsel ve sosyal destek görevi gördüğü vurgulanmaktadır (Hartup, 1996). Ayrıca yakın ilişkilerin, bireylerin sosyal ilişkilerini, içsel uyumlarını, fiziksel ve psikolojik sağlıklarını olumlu etkilediği belirtilmektedir (Moss ve Schwebel, 1993). Nitekim Dündar (2009), sosyal yaşamlarında sağlıklı ilişkiler kurabilen genç bireylerin, karşılaştıkları kişisel sorunların daha kolay üstesinden gelebildiklerini belirtmektedir. Benzer şekilde genç yetişkinler arasında kurulan yakın ilişkilerin, sosyal etkinliklere katılmaya, problem çözme becerisi kazanmaya, sosyal etkinliklerde sorumluluklar almaya ve sağlıklı bir psikolojik ve duygusal gelişim göstermeye katkı sağladığı belirtilmektedir (Newcomb ve Bagwell, 1995). Ayrıca Kantanis (2000), sağlıklı arkadaş̧ık ilişkileri kuran bireylerin üniversite yaşamındaki zorluklar ile daha kolay başa çıtıklarını ve bu bireylerin akademik başarılarının arttığını belirtmektedir.

Diğer yandan, üniversite yıllarında kurulan yakın ilişkileri olumsuz etkileyen temel etkenlerden birinin ise ilişkisel saldırganlık olduğu belirtilmektedir (Grotpeter ve Crick, 1996; Kurtyılmaz, Can ve Ceyhan, 2017). Bununla birlikte sosyal ilişkilere zarar vermeyi amaçlayan ve genel olarak dikkat çekmediği düşünülen ilişkisel saldırganlığın (Crick ve Grotpeter, 1995), en az fiziksel saldırganlık kadar zarar verici olduğu vurgulanmaktadır (Coyne, Archer ve Eslea, 2006; Underwood, Galen ve Paquette, 2001). $\mathrm{Bu}$ gelişim döneminde en sık rastlanan ilişkisel saldırganlık davranışları ise kendi amaçları için başkalarını kullanma, hoşlanmadıkları birinin kötü görünmesini sağlama, dedikodu yapma, randevuya söz verip mazeretsiz gitmeme ve dışlama olarak gösterilmektedir (Archer ve Coyne, 2005).

Türkiye'deki alanyazın incelendiğinde, ilişkisel saldırganlığın benlik saygısı, sosyal bağll1ı ve sosyal kaygı (Kurtyılmaz, 2011), ebeveyn tutumları (İkiz ve ÖztürkSamur, 2016), aile yapısı, kardeş sayısı ve cinsiyet (Uysal ve Dinçer, 2013), çevresel risk ve güvenlik algısı (Çetinkaya-Yıldız ve Hatipoğlu-Sümer, 2010), anne-baba öğrenim düzeyi (Karaca, Gündüz ve Aral, 2011) ve sosyal işlevsellik (Kındap- Tepe ve Sayıl, 2012) gibi çeşitli değişkenlerle ilişkilendirildiği gözlemlenmektedir. Diğer yandan Türkiye'de özellikle arkadaşlık ilişkileri odağında, genç-yetişkinlerin ilişkisel saldırganlık düzeyleri ile Karanlık Üçlü (Makyavelizm, narsisizm ve psikopati) kişilik özellikleri arasındaki ilişkiye odaklanan herhangi bir çalışmaya rastlanılmamıştır. $\mathrm{Bu}$ noktada, yakın ilişkiler ve kişilik gelişimi odağında, genç yetişkinlerin arkadaş ilişkilerinde sıklıkla karşılaşabilcekleri ilişkisel saldırganlık ile sahip oldukları kişilik 
özellikleri arasındaki ilişkilerin incelenmesinin alanyazına önemli bir katkı sağlayabileceği düşünülmektedir. Bununla birlikte ilişkisel saldırganlığın gelişiminde rol oynayan olası kişilik özelliklerinin belirlenmesi ile üniversite PDR merkezlerinde bu konuda yürütülebilecek önleyici çalışmalara önemli bir bakış açısı sağlanabileceği öngörülmektedir. $\mathrm{Bu}$ bilgiler ışığında bu çalışmanın amacı, Karanlık Üçlü (Makyavelizm, narsisizm ve psikopati) kişilik özelliklerinin üniversite öğrencilerinin ilişkisel saldırganlık (dışlama, manipülasyon ve dedikodu) düzeylerini yordayıp yordamadıklarını incelemektir.

\section{Yöntem}

Bu bölümde araştırma grubunun özellikleri, veri toplama araçları ve verilerin analizi ile ilgili bilgilere yer verilmiştir. Bununla birlikte, bu araştırma 01.01.2020 tarihinden önce yapıldığı için etik kurul kararı zorunluluğu taşımamaktadır.

\section{Çalışma Grubu}

$\mathrm{Bu}$ araştırmada ele alınan çalışma grubu, bir kamu üniversitesinde bulunan Eğitim, Fen-Edebiyat, İktisadi ve İdari Bilimler, İletişim, Mühendislik ve Turizm fakültelerinde öğrenim gören ve uygun örnekleme yöntemi ile berlirlenen 725 lisans öğrencisini kapsamaktadır. Çalışma grubunun 457'si (\% 63) kadın ve 268'i (\% 37) erkek öğrencilerden oluşmaktadır. Öğrencilerin yaş aralığı 18 ile 27 arasında değişmektedir ve yaş ortalaması 21.44 'tür $(\mathrm{SS}=1.82$ ). Sinıf düzeyi odağında incelendiğinde ise öğrencilerin 165 'i (\% 22.8) birinci, 187'si (\% 25.8) ikinci, 218'i (\% 30.1) üçüncü ve 155’i (\% 21.4) dördüncü sınıfta öğrenim görmektedirler.

\section{Veri Toplama Araçları}

Kişisel bilgi formu. Çalışma grubunun cinsiyet, yaş ve sınıf düzeyi gibi temel bilgilerini elde etmek üzere araştırmacılar tarafindan hazırlanan soru formudur.

Arkadaşılı ilişskilerinde ilişkisel saldırganık ölçeği (ARILSÖ). Kurtyılmaz, Can ve Ceyhan (2011) tarafindan geliştirilen ARILSÖ, 22 maddeden oluşan 5'li Likert tipi bir ölçme aracıdır. Ölçekten alınabilecek en düşük puan 23, en yüksek puan ise 115 olup puanların yüksekliği, ilişkisel saldırganlık düzeyinin arttığını göstermektedir. ARİLSÖ, dışlama, manipülasyon ve dedikodu olarak betimlenen ü̧̧ faktörden oluşmaktadır. Dışlama, kişileri yok sayma, görmezden gelme, sosyal gruplara girilmesine engel olma davranışlarını içermektedir. Bu faktöre ilişkin örnek madde: "Onun hoşlandığı etkinlikleri başkalarıyla yapmayı planlarken onu bu planlara dahil etmem." (10. madde) şeklindedir. ARILSÖ'deki diğer bir faktör olan manipülasyon, kendi amaçları doğrultusunda yönlendirmeyi içermektedir. Bu faktöre ait örnek madde "Onunla normalde paylaştı̆ıımdan daha az şey paylaşııım." (21. madde) şeklindedir. ARILSÖ'deki son faktör olan dedikodu ise kişilerin özel bilgilerini öğrenip yaymak veya haber almak amaçlı bilgi yayılımı olarak tanımlanmaktadır. Bu faktöre ait örnek madde "Onunla ilgili olumsuz yaşantılarımı başkalarıyla paylaşarak onu zor durumda bırakırım.” (3. madde) şeklindedir. 
Ölçeğin iç tutarlık katsayısı .91, test-tekrar test güvenirliği ise .93 olarak belirlenmiştir. Elde edilen bulgular, ARİLSÖ'nün yüksek düzeyde güvenilirliğe sahip olduğunu göstermektedir (Kurtyılmaz, Can ve Ceyhan, 2011). Bu çalışmada belirlenenen Cornbach alfa güvenirlik katsayıları dışlama faktörü için .91, manipülasyon faktörü için .84 ve dedikodu faktörü için .77'dir. ARILSÖ'nün toplam puanından elde edilen güvenirlik katsayısı ise .91 olarak belirlenmiştir.

Karanlık üçlü ölçeği (KÜÖ). Karanlık Üçlü Ölçeği (Short Dark Triad; SD3), Jones ve Paulhus (2014) tarafından Karanlık Üçlü kişilik özelliklerinin (Makyavelizm, narsisizm ve psikopati) belirlenmesi için geliştirilmiş bir ölçektir. Toplam 27 madde ve her biri dokuz madde ile betimlenen üç alt-ölçekten oluşan KÜÖ, 5'li Likert tipinde düzenlenmiştir. Her bir alt-ölçekten alınabilecek en düşük puan dokuz ve en yüksek puan $45^{\prime}$ tir. Alt-ölçeklerden alınan yüksek puanlar, bireylerin ilgili kişilik özelliğine yönelik eğilimlerinin yüksek olduğunu göstermektedir.

Özgün ölçeğin ilk dokuz maddesini oluşturan Makyavelizm alt-ölçeği, kendi çıkarlarını ön planda tutan, başkalarını manipüle etmekten çekinmeyen bir düşünceyi savunan kişilik özelliğini betimlemektedir. Bu alt-ölçeğe ilişkin örnek madde "Başkalarıyla doğrudan çatışma yaşamaktan kaçının çünkü bu kişiler ileride işinize yarayabilir." (madde 4) şeklindedir. KAÖ'de yer alan 10-18 arasındaki maddeler kendini üstün görme, büyüklenme, kendini aşırı önemseme olarak belirtilen narsisizm kişilik özelliğinin ölçümüne yöneliktir. Bu alt-ölçeğe ilişkin örnek madde "Ünlü kişilerle mukayese edilmişliğim vardır." (madde 16) şeklindedir. Son olarak, ölçekte yer alan 19-27 arası maddeler ise psikopati alt-ölçeği ile ilgilidir. Kontrolsüz hareket etme, ahlaki değerleri yok sayma, heyecan arayışında olma gibi tutum ve davranışları içeren psikopati alt ölçeğine ilişkin örnek madde "Başkalarına karşı kaba olabildiğim doğrudur." (madde 23) şeklindedir. Güvenirlik çalışmaları sonucunda özgün ölçeğin Cronbach alfa değerleri Makyavelizm için .71, narsisizm için .74 ve psikopati için .77 olarak belirlenmiştir (Jones ve Paulhus, 2014).

Özsoy, Rauthmann, Jonason ve Ardiç (2017) tarafindan Türkçeye uyarlanan KÜÖ, orijinal ölçeğe benzer şekilde her biri dokuz maddeden oluşan üç alt-ölçek içermektedir. Ölçeğin Türkçe formunun güvenirlik analizleri sonucunda elde edilen Cronbach alfa katsayıları sırasıyla Makyavelizm için .70, subklinik narsisizm için .79 ve subklinik psikopati için .79 olarak belirlenmiştir. Bu çalışmanın verileri incelendiğinde ise faktörlerin Cronbach alfa değerleri Makyavelizm için .71, subklinik narsisizm için .68 ve subklinik psikopati için .75 olarak belirlenmiştir.

\section{Verilerin Analizi}

Araştırma kapsamında elde edilen verilerde öncelikle çoklu regresyon sayıltıları sınanmıştır. Yapılan incelemelerde, araştırmada kullanılan ölçme araçlarından elde edilen puanların normal dağılım gösterdiği ve değişkenler arasında doğrusal bir ilişki bulunduğu belirlenmiştir. Bir sonraki aşamada ise Mahalanobis testi bulguları temelinde yordanan (ilişkisel saldırganlık) ve yordayıcı değişkenler (Makyavelizm, narsisizm ve psikopati) arasındaki Pearson korelasyon katsayıları hesaplanmıştır. 
Araştırmada yer alan değişkenler arasındaki ilişkiler incelendiğinde, Pearson korelasyon katsayılarının çoklu doğrusallığın göstergesi kabul edilen .80 düzeyinin (Gravetter ve Wallnau, 2007) altında olduğu gözlenmiştir (en yüksek .43). Ayrıca tolerans ve varyans şişkinlik (VIF) değerleri gözden geçirildiğinde, değişkenlere ait tolerans değerlerinin (.78 ile .87 arasında) .20'den büyük ve VIF değerlerinin (1.16 1.29 arasında) 10'dan küçük olduğu (Büyüköztürk, 2011), dolayısıyla değişkenler arasında çoklu doğrusallık bulunmadığı belirlenmiştir. Son olarak, Karanlık Üçlü kişilik özelliklerinin (Makyavelizm, narsisizm ve psikopati) üniversite öğrencilerinin ilişkisel saldırganlık (dışlama, manipülasyon ve dedikodu) düzeylerini yordayıp yordamadığını kontrol etmek amacıyla çoklu regresyon analizi gerçekleştirilmiştir. Araştırma verilerin analizinde SPSS.20 programı kullanılmıştır.

\section{Bulgular}

$\mathrm{Bu}$ bölümde araştırmada yer alan değişkenlere ilişkin betimsel istatistikler ile çoklu regresyon analizi sonucu elde edilen bulgular sunulmuştur.

\section{Betimsel İstatistikler}

Araştırma grubunu oluşturan 725 üniversite öğrencisi üzerinden yordanan değişkenler (ilişkisel saldırganlık, dışlama manipülasyon ve dedikodu) ile yordayıcı değişkenler (Makyavelizm, narsisizm ve psikopati) arasındaki Pearson korelasyon katsayıları Tablo 1'de sunulmaktadır.

Tablo 1

Betimsel İstatistikler ve Değişkenler Arası Korelasyonlar $(N=725)$

\begin{tabular}{lccccccc}
\hline Değişkenler & $\mathbf{1}$ & $\mathbf{2}$ & $\mathbf{3}$ & $\mathbf{4}$ & $\mathbf{5}$ & $\mathbf{6}$ & $\mathbf{7}$ \\
\hline 1. İlişkisel Saldırganlık & - & - & - & - & - & - & - \\
2. Dişlama & $.89 *$ & - & - & - & - & - & - \\
3. Manipülasyon & $.89^{*}$ & $.47^{*}$ & - & - & - & - & - \\
4. Dedikodu & $.67 *$ & $.59 *$ & $.32 *$ & - & - & - & - \\
5. Makyavelizm & $.25 *$ & $.25 *$ & $.18^{*}$ & $.17 *$ & - & - & - \\
6. Narsisizm & $.16^{*}$ & $.19 *$ & $.09 * *$ & $.09 * *$ & $.32 *$ & - & - \\
7. Psikopati & $.31 *$ & $.34 *$ & $.12 *$ & $.31 *$ & $.43 *$ & $.30 *$ & - \\
\hline Aritmetik ortalama & 47.31 & 18.32 & 22.92 & 6.07 & 27.61 & 27.46 & 21.81 \\
Standart sapma & 14.55 & 8.08 & 6.94 & 2.74 & 6.14 & 5.09 & 6.47 \\
Cronbach alfa & .91 & .91 & .84 & .77 & .71 & .68 & .75 \\
\hline
\end{tabular}

$* \mathrm{p}<.01, * * \mathrm{p}<.05$

Tablo 1 incelendiğinde, üniversite öğrencilerinin ilişkisel saldırganlık düzeyleri ile Makyavelizm $(\mathrm{r}=.25, \mathrm{p}<.01)$, narsisizm $(\mathrm{r}=.16, \mathrm{p}<.01)$ ve psikopati $(\mathrm{r}=.31$, $\mathrm{p}<.01)$ eğilimleri arasında istatistiksel açıdan pozitif yönde ve anlamlı düzeyde bir ilişki olduğu gözlemlenmiştir. Benzer şekilde, ilişkisel saldırganlığı oluşturan dışlama faktörü ile ögrencilerin Makyavelizm $(\mathrm{r}=.25, \mathrm{p}<.01)$, narsisizm $(\mathrm{r}=.19, \mathrm{p}<.01)$ ve psikopati $(\mathrm{r}=.34, \mathrm{p}<.01)$ eğilimleri arasında istatistiksel açıdan pozitif yönde ve anlamlı ilişkiler olduğu belirlenmiştir. 
Bununla birlikte, ilişkisel saldırganlığı oluşturan manipülasyon faktörü ile Makyavelizm $(\mathrm{r}=.18, \mathrm{p}<.01)$, narsisizm $(\mathrm{r}=.09, \mathrm{p}<.05)$ ve psikopati $(\mathrm{r}=.12, \mathrm{p}<$ $.01)$ eğilimleri arasında istatistiksel açıdan pozitif yönde ve anlamlı düzeyde ilişkiler görülmektedir. Aynı şekilde ilişkisel saldırganlığı oluşturan dedikodu faktörü ile Makyavelizm $(\mathrm{r}=.17, \mathrm{p}<.01)$, narsisizm $(\mathrm{r}=.09, \mathrm{p}<.05)$ ve psikopati $(\mathrm{r}=.31, \mathrm{p}<$ .01) eğilimleri arasında istatistiksel açıdan pozitif yönde ve anlamlı düzeyde ilişkilerin var olduğu belirlenmiştir.

\section{İlişkisel Saldırganlığı Yordayan Değişkenlerin İncelenmesi}

Üniversite öğrencilerinin ilişkisel saldırganlık düzeylerinin yordayıcıları olarak ele alınan Makyavelizm, narsisizm ve psikopati değişkenlerine ilişkin çoklu regresyon analizi sonuçları Tablo 2'de sunulmaktadır.

Tablo 2

İlişkisel Saldırganlığın Yordayıc Değişkenlerine İlişkin Çoklu Regresyon Analizleri

\begin{tabular}{|c|c|c|c|c|c|c|c|c|}
\hline \multicolumn{2}{|c|}{ Değişkenler } & B & $\mathrm{SH}_{B}$ & $\boldsymbol{\beta}$ & $t$ & $\mathbf{F}$ & $\mathbf{R}$ & $\mathbf{R}^{2}$ \\
\hline \multirow{4}{*}{ 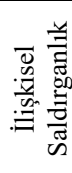 } & Sabit & 23.14 & 3.20 & - & $7.23 *$ & \multirow{4}{*}{$30.77 *$} & \multirow{4}{*}{.34} & \multirow{4}{*}{.11} \\
\hline & Makyavelizm & .33 & .09 & .14 & $3.50 *$ & & & \\
\hline & Psikopati & .52 & .09 & .23 & $5.84 *$ & & & \\
\hline & Narsisizm & .14 & .11 & .05 & 1.26 & & & \\
\hline \multirow{4}{*}{ 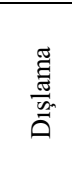 } & Sabit & 3.97 & 1.76 & - & $2.26^{*}$ & \multirow{4}{*}{$36.50 *$} & \multirow{4}{*}{.36} & \multirow{4}{*}{.13} \\
\hline & Makyavelizm & .14 & .05 & .11 & $2.78 *$ & & & \\
\hline & Psikopati & .34 & .05 & .27 & $6.93 *$ & & & \\
\hline & Narsisizm & .11 & .06 & .07 & 1.83 & & & \\
\hline \multirow{4}{*}{ 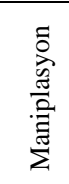 } & Sabit & 16.18 & 1.59 & - & $10.16^{*}$ & \multirow{4}{*}{$8.47 *$} & \multirow{4}{*}{.19} & \multirow{4}{*}{.04} \\
\hline & Makyavelizm & .16 & .05 & .14 & $3.47 *$ & & & \\
\hline & Psikopati & .06 & .04 & .05 & 1.26 & & & \\
\hline & Narsisizm & .04 & .05 & .03 & .70 & & & \\
\hline \multirow{4}{*}{$\begin{array}{l}\vec{z} \\
0 \\
\frac{y}{3} \\
0 \\
0\end{array}$} & Sabit & 2.98 & .61 & - & $4.91 *$ & \multirow{4}{*}{$26.40 *$} & \multirow{4}{*}{.32} & \multirow{4}{*}{.10} \\
\hline & Makyavelizm & .02 & .02 & .05 & 1.30 & & & \\
\hline & Psikopati & .13 & .02 & .29 & $7.38 *$ & & & \\
\hline & Narsisizm & .01 & .02 & .02 & .49 & & & \\
\hline
\end{tabular}

Buna göre Makyavelizm ve psikopati kişilik özelliklerinin üniversite öğrencilerinin ilişkisel saldırganlık düzeylerini anlamlı şekilde yordadıkları (F(3, $721)=30.77, \mathrm{p}<.001, \mathrm{R}=.34, \mathrm{R}^{2}=.11$ ) ve sözü edilen bu iki kişilik özelliğinin öğrencilerin ilişkisel saldırganlık düzeylerine ait olan toplam varyansın \% 11'ini açıkladıkları gözlemlenmektedir. Standardize edilmiş regresyon katsayıları ele alındığında $(\beta)$ ise yordayıcı değişkenlerin ilişkisel saldırganlık düzeyi üzerindeki önem sırası psikopati $(\beta=.23, \mathrm{t}=5.84, \mathrm{p}<.001)$ ve Makyevalizm $(\beta=.14, \mathrm{t}=3.50, \mathrm{p}<$ 
.001) şeklindedir. Diğer yandan, narsisizm kişilik özelliğinin üniversite öğrencilerinin ilişkisel saldırganlık düzeylerini yordamadığı belirlenmiştir $(\beta=.05, \mathrm{t}=1.26, \mathrm{p}=.21)$.

Tablo 2'de sunulan araştırma bulguları ilişkisel saldırganlığın alt boyutları açısından incelendiğinde, Makyavelizm ve psikopati eğilimlerinin üniversite öğrencilerinin arkadaş ilişkilerindeki dışlama düzeylerini anlamlı șekilde yordadıkları $\left(\mathrm{F}(3,721)=36.50, \mathrm{p}<.001, \mathrm{R}=.36, \mathrm{R}^{2}=.13\right)$ ve sözü edilen bu iki kişilik özelliğinin öğrencilerin ilişkisel saldırganlık düzeylerine ait olan toplam varyansın \% 13'ünü açıkladıkları görülmektedir. Standardize edilmiş regresyon katsayıları incelendiğinde ise yordayıcı değişkenlerin öğrencilerin dışlama düzeyleri üzerindeki önem sırası psikopati $(\beta=.27, \mathrm{t}=6.93, \mathrm{p}<.001)$ ve Makyevalizm $(\beta=.11, \mathrm{t}=2.78, \mathrm{p}<.001)$ şeklindedir. Diğer yandan üniversite öğrencilerinin narsisizm eğilimlerinin arkadaş ilişkilerindeki dışlama düzeyini yordamadığı belirlenmiştir $(\beta=.07, \mathrm{t}=1.83, \mathrm{p}=.07)$.

Araştırma bulguları ilişkisel saldırganlığın manipülasyon alt boyutu açısından incelendiğinde (Tablo 2), sadece Makyavelizm kişilik özelliğinin üniversite öğrencilerinin arkadaş ilişkilerindeki manipülasyon düzeylerini anlamlı şekilde yordadı $\breve{g}_{1}\left(\mathrm{~F}(3,721)=8.47, \mathrm{p}<.001, \mathrm{R}=.19, \mathrm{R}^{2}=.04\right)$ ve sözü edilen bu kişilik özelliğinin $(\beta=.14 ; \mathrm{t}=3.47, \mathrm{p}<.001)$ öğrencilerin manipülasyon düzeylerine ait olan toplam varyansın \% 4'ünü açıkladığı gözlemlenmektedir. Diğer yandan üniversite ögrencilerinin narsisizm $(\beta=.03 ; \mathrm{t}=.70, \mathrm{p}=.49)$ ve psikopati $(\beta=.05 ; \mathrm{t}=1.26, \mathrm{p}=.21)$ eğilimlerinin arkadaş ilişkilerindeki manipülasyonu yordamadığı belirlenmiştir.

Araştırma bulguları ilişkisel saldırganlığın dedikodu alt boyutu açısından incelendiğinde (Tablo 2) ise bu kez sadece psikopati kişilik özelliğinin üniversite öğrencilerinin dedikodu düzeylerini anlamlı şekilde yordadığı $(F(3,721)=26.40, \mathrm{p}<$ $\left..001, \mathrm{R}=.32, \mathrm{R}^{2}=.10\right)$ ve sözü edilen bu kişilik özelliğinin $(\beta=.29 ; \mathrm{t}=7.38, \mathrm{p}<.001)$ öğrencilerin dedikodu düzeylerine ait toplam varyansın $\% 10$ 'unu açıkladığ görülmektedir. Diğer yandan üniversite öğrencilerinin Makyavelizm $(\beta=.05 ; \mathrm{t}=1.30$, $\mathrm{p}=.19)$ ve narsisizm $(\beta=.02 ; \mathrm{t}=.49, \mathrm{p}=.63)$ eğilimlerinin arkadaş ilişkilerindeki dedikodu düzeyini yordamadığı belirlenmiştir.

\section{Tartışma, Sonuç ve Öneriler}

$\mathrm{Bu}$ bölümde, araştırma sonucunda elde edilen bulgular alanyazın odağında tartışılmış, gelecekteki uygulama ve çalışmalara yönelik öneriler sunulmuştur.

\section{İlişkisel Saldırganlığı Yordayan Karanlık Üçlü Kişilik Özellikleri}

Araştırma bulguları, üniversite öğrencilerinin ilişkisel saldırganlık düzeylerini anlamlı ve düşük düzeyde yordayan Karanlık Üçlü kişilik özelliklerinin sırasıyla psikopati ve Makyavelizm olduğunu göstermektedir. İlgili alanyazında da üniversite öğrencilerinin psikopati eğilimlerinin artmasına bağlı olarak ilişkisel saldırganlığını arttırdığı yönünde çeşitli çalışmalar (Banks, Forsyth, O’Boyle ve Story, 2013; Coyne ve Thomas, 2008; Czar ve diğ., 2010; Jones ve Neria, 2015; Kerig ve Stellwagen, 2010) bulunmaktadır. Dolayısıyla üniversite öğrencilerini kapsayan bu çalışmanın bulguları alanyazını destekler niteliktedir. Bulgular ayrıca farklı örneklem grupları 
(mahkumlar, çocuklar, öğrenciler, ergenler, öğretmenler vb.) ile yapılmış çalışmaların (Archer, 2004; Lehmann ve Ittel, 2012; Marsee, Silverthorn ve Frick, 2005; Schmeelk ve diğ., 2008) sonuçları ile de büyük oranda paralellik göstermektedir.

Warren ve Clarbour'a (2009) göre empatik eğilimleri düşük olan psikopatlar, sosyal ilişkilerdeki duygusal beceri eksikliğinden dolayı, diğerlerini kontrol etmek için ilişkilerinde daha fazla ilişkisel saldırganlık davranışı sergilemektedirler. $\mathrm{Bu}$ noktada Knight ve diğ. (2018), varolan empati yoksunluğu çerçevesinde şekillenen başkaları üzerinde hak iddia edebileceklerine yönelik inançları temelinde psikopatik eğilimli bireylerin ilişkisel saldırganlığa başvurma olasılıklarının arttığını belirtmektedirler. Bilindiği üzere empatik eğilimleri yüksek olan bireyler, başkalarını düşünme, onlara sayg duyma, onlarla sağlıklı iletişim için özveride bulunma, olayları farklı kişilerin bakış açısından inceleme davranışlarına sahiptirler (Çankaya ve Ergin, 2015). Dolayısıyla empati yoksunluğu, aşırı dürtüsellik ve kendini kontrol edememe davranışlarına sahip olan psikopati eğilimi yüksek bireylerin (Paulhus ve Williams, 2002), arkadaş ilişkilerinde ilişkisel saldırganlığa başvurma olasılıklarının fazla olması anlaşılır bir durum olmaktadır.

Üniversite öğrencilerinde ilişkisel saldırganlığı düşük düzeyde yordayan ikinci kişilik özelliği ise Makyavelizm'dir. Eldeki bulgular, alanyazında yer alan çeşitli çalışmaları (Abell ve Brewer, 2014; Jones ve Neria, 2015; Kerig ve Stellwagern, 2010; Peeters ve diğ., 2010; Pursoo, 2013; Sutton ve Keogh, 2000) destekler niteliktedir. Bu noktada Abell ve Brewer (2014), Makyavelizm eğilimi olan bireyleri kendi amaçları için başkalarını kullanmaktan çekinmeyen ve bu yüzden onlara karşı ilgiliymiş gibi davranan bireyler olarak tanımlamaktadırlar. Dolayısıyla Makyavelizmdeki olumsuz dünya algısı çerçevesinde (Jones ve Neria, 2015) ahlaksal değerlerden uzaklaşmaya bağlı olarak (Pursoo, 2013) kendi amaçları için başkalarını kullanma, dedikodu çıkarma, gruptan dışlama, söylentiler çıkarma tehdidiyle diğerlerini kullanma gibi doğrudan sergilenmeyen ilişkisel saldırganlık davranışlarının (Loukas, Paulos ve Robinson, 2005) artması anlaşılabilir bir durumdur.

Diğer yandan bulgular, narsisizm kişilik özelliğinin üniversite öğrencilerinin arkadaşlık ilişkilerindeki ilişkisel saldırganlık düzeylerini (dışlama, manipülasyon ve dedikodu faktörleri de dahil olmak üzere) anlamlı bir şekilde yordamadığını göstermektedir. Bu noktada Coyne ve Thomas (2008), narsisizmin saldırganlık ile ilişkili olmadığını, narsist bireylerin ego tehdidi ile karşılaşmadıkları ve kışkırtılmadıkları sürece saldırganlık davranışlarına başvurmadıklarını belirtmektedirler. Aslında narsist bireyler, kendilerine çok güvenilir görülen, daha çok kendilerini düşünen bireyler olarak algılanmalarına karşın, başkaları tarafından parmakla gösterilen, ilgiyle takip edilen biri olmak adına sosyalleşmeye çok değer verirler (Young ve Pinsky, 2006). Narsisizm eğilimi olan bireyler için toplum tarafindan beğenilmek ve takdir edilmelerini sağlayacak sosyal çevrelerde bulunmak çok önemlidir. Bu amaçla narsist bireylerin daha çok istendik bireyler olma çabasında bulunmaları kaçınılmaz olmaktadır (Campbell ve Campbell, 2009). Dolayısıyla 
başkaları tarafından tercih edilme gereksinimi temelinde narsistik eğilimlerin baskılanabileceği ya da ilişkilere farklı şekillerde yansıtabileceği göz ardı edilmemelidir. Bunlara ek olarak narsist bireylerin, Makyavelist ve psikopat bireylere göre daha yüksek bir benlik saygısına sahip oldukları, kendilerini daha iyi ifade ettikleri ve ilişkisel saldırganlığı daha az tercih ettikleri belirtilmektedir (Falkenbach, Howe ve Falki, 2013; Rose, 2002). Bu bilgiler ışı̆̆ında, ilişkisel saldırganlık ve faktörlerinin narsisizm tarafindan yordanmaması anlaşılır bir durum olarak değerlendirilmektedir.

\section{İlişkisel Saldırganlık Dışlama Boyutunu Yordayan Karanlık Üçlü Değişkenleri}

Araştırma bulguları arkadaşlık ilişkilerinde ilişkisel saldırganlığın dışlama boyutu açısından incelendiğinde, üniversite öğrencilerinin ilişkisel saldırganlık odağında dışlama düzeylerini anlamlı ve düşük düzeyde yordayan kişilik özelliklerinin Makyavelizm ve psikopati olduğu görülmektedir. Bu çalışmadan elde edilen bulgular, alanyazındaki çalışma bulguları ile (Masui, Fujiwara ve Ura, 2013; Masui, Iriguchi, Terada, Nomura ve Ura, 2012; Leary, Twenge ve Quinlivan, 2006; Warburton, Williams ve Cairns, 2006) paralellik göstermektedir.

Bulgular, dışlamayı en güçlü yordayan değişkenin psikopati olduğunu göstermektedir. Masui ve diğ., (2013), varolan sorunları görmezden gelme, kendini küçümseme ya da yok sayma olarak nitelendirilen olumsuz mizaç stillerine (Martin, Lastuk, Jeffery, Vernon ve Vesel, 2012) sahip psikopati özelliği sergileyen bireylerin, sosyal ilişkilerinde sıklıkla dışlama eğilimi gösterdiklerini belirtmektedirler. $\mathrm{Bu}$ noktada Masui ve diğ. (2012), psikopatik eğilimlere bağlı olarak dişlama tutum ve davranışlarının artmasını sosyal destek yetersizliğine bağlamaktadırlar. Benzer şekilde Leary, Twenge ve Quinlivan (2006), sosyal destek yetersizliğinin bu bireyleri saldırganlık, dışlama ya da dışlanmaya yönelttiğgini ve sosyal reddetme ile psikopatik eğilimlerin ilişkili olabileceğini ifade etmektedirler. Nitekim Coyne ve Thomas (2008), psikopatinin sosyal gruplarda dışlanmaya neden olabilecek ya da grup içinde dışlama davranışlarının dışavurumunu sağlayabilecek bir kişilik özelliği olduğunu belirtmektedir. Dolayısıyla sosyal destek yetersizliğinin bireyleri saldırganlığa yöneltebileceği (Masui ve diğ., 2012) bulgusundan hareketle psikopati eğilimi sergileyen bireylerin, kendilerini dışlanmış olarak algılamalarına bağlı olarak ya da içinde bulundukları gruptan dışlanmamak adına başkalarını dışlama davranışlarına yönelmeleri oldukça olası görünmektedir.

Araştırma bulgularına göre üniversite öğrencilerinin dışlama düzeylerini anlamlı ve düşük düzeyde yordayan diğer bir kişilik özelliği ise Makyavelizmdir. İlgili alanyazında da Makyavelizmin ilişkisel saldırganlığa ve özellikle dışlamaya neden olduğuna yönelik çalışmalar (Erdoğan, 2018; LaFontana ve Cillessen, 2002; O’boyle ve diğ., 2012; Peeters, Cillessen ve Scholte, 2010) bulunmaktadır. Alanyazında, kendilerini güvende hissetmek ya da bir yere ait hissetmek adına Makyavelist bireylerin aidiyet duygularına gelebilecek her türlü olumsuzluk karşısında dışlama davranışlarına başvurabilecekleri belirtilmektedir (Abrams, Hogg ve Marques 2004). Dolayısıyla grup içinde tehdit olarak algılanan diğer bireylere yönelik dışlama 
girişimlerinin olması (Loudin, Loukas ve Robinson, 2003) özellikle Makyavelist bireyler açısından kaçınılmaz bir davranış olarak görülmektedir.

\section{İlişskisel Saldırganlık Manipülasyon Boyutunu Yordayan Karanlık Üçlü Kişilik Özellikleri}

Araştırma bulguları ilişkisel saldırganlığın manipülasyon alt boyutu açısından incelendiğinde, üniversite öğrencilerinin arkadaşlık ilişkilerindeki manipülasyon düzeylerini anlamlı ve düşük düzeyde yordayan tek kişilik özelliğinin Makyavelizm olduğu görülmektedir. Bu çalışmadan elde edilen bulgular ile alanyazında yer alan benzer çalışma bulguları (Abell ve Brewer, 2014; Abell, Brewer, Qualter ve Austin, 2016; Austin ve diğ., 2007) dikkat çekmektedir.

Makyavelist özelliklere sahip bireyler, diğerlerinin saf ve deneyimsiz olduklarına ve kolay kandırılabileceklerine inanırlar, dolayısıyla başkalarını kendi amaçları doğrultusunda yönlendirme konusunda endişe yaşamazlar (Toplu-Yaşlıŏlu ve Atılgan, 2018). Aynı zamanda Makyavelist bireylerin diğerlerinin duygularını oldukça iyi anladıkları ancak bu özelliklerini sıklıkla başkalarını manipüle etme amacıyla kullandıkları vurgulanmaktadır (Barnett ve Thompson, 1985; Hawley, Little ve Pasupathi, 2002). Başka bir deyişle Makyavelist eğilimleri yüksek olan bireylerde başkalarını kendi istekleri doğrultusunda yönlendirme ve kontrol etme isteği vardır (Dahling, Whitaker ve Levy, 2008). Dolayısıyla yaptıkları hileli yönlendirmelerde haklılık payı olduğunu düşünmeleri ve öznel amaçları için mantıklı nedenler bulma uğraşları odağında başkaları ile mücadelede manipülasyonu sadece bir araç olarak gören Makyavelist bireylerin (O’boyle ve diğ., 2012) arkadaş ilişkilerindeki manipülasyon düzeylerinin yüksek olması oldukça anlaşılır bir durum olmaktadır.

Diğer bir açıdan Ináncsi, Láng ve Bereczkeia (2015), Makyavelist bireylerin bağlanmadan kaçınma davranışları içinde olabileceklerini belirtmektedir. Buna göre Makyavelistler uzun süreli ilişkilerden kaçınmakta, ikili ilişkilerinde yararcılık anlayışıyla diğer bireylerden yararlanma ve onları manipüle etme eğilimi göstermektedirler (Paal ve Bereczkei, 2007). Dolayisıyla Makyavelist bireyler, yararlandıkları kişilerden alınabilecek herhangi bir şey kalmadığında oluşabilecek sorunlar ile karşılaşmamak amacıyla manipülasyonlara başvurarak ilişkilerini sonlandırma girişimde bulunabilirler (Ali ve Chamorro-Premuzic, 2010).

$\mathrm{Bu}$ çalışmanın bulguları, üniversite öğrencilerin arkadaşılık ilişkilerinde görülen manipülasyonun, psikopati kişilik özelliği tarafından yordanmadığını göstermektedir. Bilindiği üzere manipülasyonda planlı hareket etme, ulaşılmak istenen amaç için belirli bir strateji oluşturma ve dikkat çekmeme davranışları (Özsoy ve Ardıç, 2017) görülmektedir. Yine manipülasyonda, yakın ilişkilerin kurulması önemli olmakta ve istenilen amaca ulaşılana kadar yakın ilişkiler özenle korunmaktadır (Paal ve Bereczkei, 2007). Diğer yandan, psikopati eğilimleri olan bireylerde genel olarak düşüncesizce davranma (Özsoy ve Ardıç, 2017), elde edilmek istenen amacın büyüklüğü ya da küçüklüğü önemsenmeden, sadece bir şeyi elde etmek odaklı her türlü tehlikeli ve suç sayılabilecek işlere kalkışma, sosyal yaşamda amaçsız ve plansız 
hareket etme (Erdoğan, 2018) davranışları görülmektedir. Bununla birlikte psikopati eğilimi olan bireylerde, sosyal ilişkilerinde yakınlık gösterememe ya da ilişkiyi sürdürememe durumu söz konusudur (Özsoy ve Ardıç, 2017). Bu açıklamalar temelinde, ilişkisel saldırganlık alt boyutu olan manipülasyonun psikopati tarafindan yordanmaması anlamlı görülmektedir.

\section{İlişkisel Saldırganlık Dedikodu Boyutunu Yordayan Karanlık Üçlü Kişilik Özellikleri}

Araştırma bulguları arkadaşlık ilişkilerindeki ilişkisel saldırganlığın dedikodu alt boyutu açısından incelendiğinde, üniversite öğrencilerinin arkadaşlık ilişkilerinde dedikodu düzeylerini anlamlı ve düşük düzeyde yordayan tek kişilik özelliğinin psikopati olduğu görülmektedir. Buna göre üniversite öğrencilerinin psikopati eğilimleri arttıkça arkadaş ilişkilerindeki dedikodu düzeyleri de artmaktadır. Eldeki bulgular, ilgili alanyazında şu ana kadar psikopati ile dedikodu arasındaki ilişkilere odaklanan tek bir çalışmanın (Lyons ve Hughes, 2015) bulguları ile paralellik göstermektedir.

Dedikodu, rahatsızlık duyulan kişilerin toplum içinde kötü görünmelerini sağlamak ve onlara zarar vermek amacıyla yanlış bilgilerin yayılması olarak tanımlanmaktadır (Baumeister ve diğ., 2004; McAndrew, 2014; Solmaz, 2006). Bu noktada Lyons ve Hughes (2015), psikopatik eğilimleri olan bireylerin hoşlanmadıkları diğer bireyler ile ilgili dedikoduya sıklıkla başvurduklarını vurgulamaktadır. Dolayısıyla empati yoksunluğu, aşırı dürtüsellik ve kendini kontrol edememe davranışlarıyla nitelendirilen psikopati eğilimi yüksek bireylerin (Paulhus ve Williams, 2002), başkalarının ne düşündüğü ile ilgilenmeden arkadaşlık ilişkilerinde dedikodu yaparak diğerlerine zarar vermeye çalışmaları ya da kişisel amaçlarına ulaşmak adına dedikoduya başvurmaları oldukça olası görünmektedir.

Son olarak, üniversite öğrencilerinin arkadaşlık ilişkilerinde görülen dedikodunun Makyavelizm kişilik özelliği tarafından yordanmadığı görülmektedir. Makyavelist bireylerin başkaları tarafindan olumsuz değerlendirilmekten çekindikleri, akranları tarafindan reddedilmekten endişe duydukları ve bu yüzden diğer bireylere doğrudan, fark edilebilecek, dikkat çekilebilecek olumsuz davranışlar sergilemekten kaçındıkları belirtilmektedir (Loukas ve diğ., 2005). Dolayısıyla başkaları tarafından reddedilme kaygısı temelinde Makyavelist tutum ve davranışların arkadaşlık ilişkilerine farklı şekillerde yansitılabileceği göz önünde bulundurulmalıdır.

Üniversite yıllarında kurulan arkadaşlık ilişkilerinin üniversite öğrencilerinin gelişimlerine olumlu katkı sağladığı (Astin, 1993) bilinmektedir. Bu noktada, üniversite yıllarında kurulan sosyal ilişkiler, aynı zamanda öğrencilerin kendini üniversiteye ait hissetmelerinde etkili olmaktadır (Sevinç-Tuhanioğlu, 2017). Ayrıca, sağlıklı bir sosyal ortamda bulunan üniversite öğrencilerinin akademik başarılarında artış ve sorunlu davranışlarında azalma görülmektedir (Pittman ve Richmond, 2008). Diğer yandan, sosyal ilişkilerinde sorunlar yaşayan ve kendini bir gruba ait 
hissetmeyen bireylerin çeşitli psikolojik sorunlar yaşamaları oldukça olasıdır. Bu bakış açısıyla üniversite PDR merkezleri aracılığıyla üniversite öğrencilerinde ilişkisel saldırganlık davranışlarının en aza indirilmesi için çeşitli gelişimsel ve önleyici çalışmaların yapılması önemlidir. Bu bağlamda üniversite öğrencilerine yönelik duyguları yönetebilme, özfarkındalık kazanma ve empatik anlayış geliştirme vb. konularda çeşitli grup rehberliği çalışmaları yapılabilir. Benzer şekilde üniversite PDR merkezlerinde, etkili iletişim, çatışma çözme, girişkenlik, kişilerarası ilişkiler odaklı çeşitli sosyal becerileri geliştirmeyi temel alan psiko-eğitim programları geliştirilebilir. Bu sayede ilişkisel saldırganlık davranışları sergileyen bireylerin farkındalık kazanmalarına ve daha sağlıklı arkadaşlık ilişkileri geliştirmelerine yönelik önleyici ve gelişimsel bir yaklaşım sağlanabilir.

Farklı bir bakış açısıyla benlik saygısının bireylerin psikolojik gelişimlerinde sahip olduğu önem dolayısıyla (Ackerman ve diğ., 2010; Rose, 2002) özellikle Karanlık Üçlü kişilik özelliklerinin bireyler üzerindeki olumsuz etkilerinin en aza indirilmesinin, bireylerin benlik saygısının arttırılması ile sağlanabileceği değerlendirilmektedir. Çünkü güçlü bir benlik saygısına sahip bireylerin dış çevreye olan bağımlılıklarının azalmasının ve güçlü olumlu duygulara sahip olunmasının olası olduğu belirtilmektedir. Dolayısıyla yüksek benlik saygısına sahip bireylerin özellikle saldırganlık davranışlarını tercih etmeyecekleri belirtilmektedir (Falkenbach ve diğ., 2013). Bu yüzden bireylerin benlik saygısını arttırmaya yönelik psikoeğitimsel çalışmalar yürütülebilir.

$\mathrm{Bu}$ çalışmada, üniversite öğrencilerinde ilişkisel saldırganlık düzeyinin olumsuz kişilik özellikleri olarak tanımlanan Karanlık Üçlü değişkenleri tarafından yordanıp yordanmadığı incelenmiştir. Gelecekte, ilişkisel saldırganlıkla ilişkili olabilecek ve olumlu kişilik özelliklerini kapsayan HEXACO gibi farklı kişilik modelleri ile ya da farklı değişkenlerle (yalnızlık, depresyon, sosyal kaygı, öfke, akran reddi, sinizm, zayıf dürtü kontrolü, bağlanma stilleri, flört şiddeti, duygusal tükenme, kıskançlık, ilişkisel mağduriyet vb.) çalışlabilir. Bu çalışmada, üniversite öğrencilerinin arkadaşlık ilişkilerindeki ilişkisel saldırganlığa odaklanılmaktadır. İlerleyen çalışmalarda, romantik ilişkilerde ilişkisel saldırganlık üzerine odaklanılabilir. Ayrıca, arkadaşlık ilişkilerinde ilişkisel saldırganlık düzeyinin içinde bulunulan gelişim dönemine, yaşa, sosyal çevreye, aile ve arkadaşlık ilişkilerine göre değişkenlik gösterip göstermemesinin incelenmesi amacıyla boylamsal çalışmalar yapılabilir. Son olarak, bu çalışmada ele alınan değişkenler ile yukarıda çalışılması önerilen değişkenler temelinde üniversite öğrencilerinde ilişkisel saldırganlığa etki eden faktörler arasındaki ilişkilerin ya da bu faktörlerin olası aracı rollerinin daha iyi anlaşılması amacıyla yapısal eşitlik modelinin kullanıldığı çalışmalar gerçekleştirilebilir. Bu araştırmanın verileri sadece bir devlet üniversitesinde öğrenim gören üniversite öğrencilerinden elde edilmiştir. Bu durum, araştırma sonuçlarının genellenebilirliği açısından bir sınırlılık olarak değerlendirilebilir. Benzer şekilde, araştırma grubunda yer alan erkek katılımcıların oranının kadın katılımcılara göre düşük olmasına bağlı olarak sonuçların cinsiyet odağında ele alınmasında dikkatli davranılmalıdır. 


\section{Etik Kurul Kararı}

$\mathrm{Bu}$ araştırma, 01.01.2020 tarihinden önce yapıldığı için etik kurul kararı zorunluluğu taşımamaktadır.

\section{Kaynakça}

Abayhan, Y. (2013). Sosyal etki kuramı bağlamında psikolojik dışlanma (Yayımlanmamış doktora tezi). https://tez.yok.gov.tr/UlusalTezMerkezi/'nden erişilmiştir (Tez No. 339022).

Abell, L., and Brewer, G. (2014). Machiavellianism, self-monitoring, self-promotion and relational aggression on Facebook. Computers in Human Behavior, 36, 258262.

Abell, L., Brewer, G., Qualter, P., and Austin, E. (2016). Machiavellianism, emotional manipulation, and friendship functions in women's friendships. Personality and Individual Differences, 88, 108-113.

Abrams, D., Hogg, M. A., and Marques, J. M. (2004). Social psychology of inclusion and exclusion. New York: Psychology Press.

Ackerman, R. A., Witt, E. A., Donnellan, M. B., Trzesniewski, K. H., Robins, R. W., and Kashy, D. A. (2010). What does the narcissistic personality inventory really measure? Assessment, 18(1), 67-87.

Ali, F., and Chamorro-Premuzic, T. (2010). The dark side of love and life satisfaction: Associations with intimate relationships, psychopathy and Machiavellianism. Personality and Individual Differences, 48, 228-233.

Archer, J. (2004). Sex differences in aggression in real-world settings: A metaanalytic review. Review of General Psychology, 8, 291-322.

Archer, J., and Coyne, S. M. (2005). An integrated review of indirect, relational, and social aggression. Personality and Social Psychology Review, 9(3), 212-230.

Ashton, M. C., and Lee, K. (2001). A theoretical basis for the major dimensions of personality. European Journal of Personality, 15, 327-353.

Ashton, M. C., Book, A., Hodson, G., Lee K., Visser, B. A., and Volk, A. A. (2018). Is the dark triad common factor distinct from low honesty-humility? Journal of Research in Personality, 73, 123-129.

Astin, A. W. (1993). What matters in college? Four critical years revisited. San Francisco: Jossey-Bass Publishers

Austin, E. J., Farrelly, D., Black, C., and Moore, H. (2007). Emotional intelligence, Machiavellianism and emotional manipulation: Does EI have a dark side? Personality and Individual Differences, 43, 179-189. 
Aydın, A. ve Akgün, S. (2014). Ergenlikte reaktif-proaktif saldırganlık, öfke ve narsisizm ilişkisi. Türk Psikoloji Dergisi, 29(73), 44-56.

Barnett, M. A., and Thompson, S. (1985). The role of perspective taking and empathy in children's Machiavellianism, prosocial behavior, and motive for helping. Journal of Genetic Psychology, 146, 295-305.

Banks, G. C., Forsyth, D., O'Boyle, E. H., and Story, P. A. (2013). A meta-analytic review of the Dark Triad-intelligence connection. Journal of Research in Personality, 47(6), 789-794.

Baumeister, R. F., Kathleen, L., and Vohs, D. (2004). Gossip as cultural learning. Review of General Psychology, 8(2), 111-121.

Beersma, B., and Van Kleef, G. A. (2012). Why people gossip: An empirical analysis of social motives, antecedents, and consequences. Journal of Applied Social Psychology, 42(11), 2640-2670.

Buss, D. M., Gomes, M., Higgins, D. S., and Lauterbach, K. (1987). Tactics of manipulation. Journal of Personality and Social Psychology, 52(6), 1219-1229.

Büyüköztürk, Ş. (2011). Sosyal bilimler için veri analizi el kitabı (13. Baskı). Ankara: Pegem Akademi.

Campbell, W. K., and Campbell, S. M. (2009). On the self-regulatory dynamics created by the peculiar benefits and costs of narcissism: A contextual reinforcement model and examination of leadership. Self and Identity, 8(2-3), 214-232.

Christie, R., and Geis, F. L. (1970). Studies in Machiavellianism. New York: Academic Press.

Coyne, S. M., Archer, J., and Eslea, M. (2006). "We're not friends anymore! Unlessy": The frequency and harmfulness of indirect, relational, and social aggression. Aggression Behavior, 32, 294-307.

Coyne, S. M., and Thomas, T. J. (2008). Psychopathy, aggression, and cheating behavior: A test of the Cheater-Hawk hypothesis. Personality and Individual Differences, 44(5), 1105-1115.

Czar, K. A., Dahlen, E. R., Bullock, E. E., and Nicholson, B. C. (2010). Psychopathic personality traits in relational aggression among young adults. Aggressive Behavior, 37(2), 207-214.

Çankaya, G. ve Ergin, H. (2015). Çocukların oynadıkları oyunlara göre empati ve saldırganlık düzeylerinin incelenmesi. Hacettepe Üniversitesi Sağllk Bilimleri Fakültesi Dergisi,1(2), 283-297. 
Çetinkaya-Yıldız, E. ve Hatipoğlu-Sümer, Z. (2010). Saldırgan davranışlarını yordamada çevresel risk, çevresel güvenlik ve okul iklimi algısı. Türk Psikolojik Danı̧̧ma ve Rehberlik Dergisi, 4(34) 161-173.

Dahling, J. J., Whitaker, B. G., and Levy, P. E. (2008). The development and validation of a new Machiavellianism scale. Journal of Management, 35(2), 219257.

Demir, N. Ö., Görgün-Baran, A. ve Ulusoy, D. (2005). Türkiye'de ergenlerin arkadaşakran grupları ile ilişkileri ve sapmış davranışlar: Ankara örneklemi. Ahmet Yesevi Üniversitesi Bilig Dergisi, 32, 83-108.

Dunbar, R. I. M. (2004). Gossip in evolutionary perspective. Review of General Psychology, 8(2), 100-110.

Dündar, S. (2009). Üniversite öğrencilerinin kişilik özellikleri ile problem çözme becerileri arasındaki ilişkinin incelenmesi. Dokuz Eylül Üniversitesi İktisadi ve İdari Bilimler Fakültesi Dergisi, 24(2), 139-150.

Ellwardt, L., Labianca, G. (Joe), and Wittek, R. (2012). Who are the objects of positive and negative gossip at work? Social Networks, 34(2), 193-205.

Erdoğan, B. (2018). Karanlık üçlü kişilik özelliklerine sahip üniversite ögrrencileriyle kendine zarar verme davranışl gösterenlerin saldırganlık ve risk alma davranışlarının karşılaştırılması (Yayımlanmamış yüksek lisans tezi). https://tez.yok.gov.tr/UlusalTezMerkezi/'nden erişilmiştir (Tez No. 528135).

Eryılmaz, A. ve Ercan, L. (2011). Öznel iyi oluşun cinsiyet, yaş grupları ve kişilik özellikleri açısından incelenmesi. Türk Psikolojik Danışma ve Rehberlik Dergisi, 4(36), 139-151.

Falkenbach, D. M., Howe, J. R., and Falki, M. (2013). Using self-esteem to disaggregate psychopathy, narcissism, and aggression. Personality and Individual Differences, 54(7), 815-820.

Foster, E. K. (2004). Research on gossip: Taxonomy, methods, and future directions. Review of General Psychology, 8(2), 78-99.

García, G. M. (2009). Narcissism, self-esteem, and self-worth as predictors of aggression (Unpublished master's thesis). https://scholar.utc.edu/theses/269/ adresinden erişilmiştir.

Gravetter, F. J., and Wallnau, L. B. (2007). Statistics for the behavioral sciences (7th Ed.). Belmont: Thomson Wadsworth.

Grieve, R., and Mahar, D. (2010). The emotional manipulation-psychopathy nexus: Relationships with emotional intelligence, alexithymia and ethical position. Personality and Individual Differences, 48(8), 945-950. 
Grotpeter, J. K., and Crick, N. R. (1996). Relational aggression, overt aggression, and friendship. Child Development, 67(5), 2328-2338.

Goldberg, L. R. (1990). The structure of phenotypic personality traits. American Psychologist, 48, 26-34.

Hartung, F. M., Krohn, C., and Pirschtat, M. (2019). Better than its reputation? Gossip and the reasons why we and individuals with "dark" personalities talk about others. Frontiers in Psychology, 10, 1-16.

Hartup, W. W. (1996). The company they keep: Friendships and their developmental significance. Child Development, 67(1), 1-13.

Hawley, P. H., Little, T. D., and Pasupathi, M. (2002). Winning friends and influencing peers: Strategies of peer influence in late childhood. International Journal of Behavioral Development, 26, 466-474.

Ináncsi, T., Láng, A., and Bereczkeia, T. (2015). Machiavellianism and adult attachment in general interpersonal relationships and close relationships. Europe's Journal of Psychology (EJOP), 11(1), 139-154.

İkiz, S. ve Öztürk-Samur, A. (2016). Okul öncesi dönem çocuklarında fiziksel ve ilişkisel saldırganlığın ebeveyn tutumları açısından incelenmesi. Mustafa Kemal Üniversitesi Sosyal Bilimler Enstitüsü Dergisi, 13(35), 159-175.

Jonason, P. K. Richardson, E. N., and Potter, L. (2015). Self-reported creative ability and the dark triad traits: An exploratory study. American Psychological Association, 9(4), 488-494.

Jones, D. N., and Neria, A. L. (2015). The dark triad and dispositional aggression. Personality and Individual Differences, 86, 360-364.

Jones, D. N., and Paulhus, D. L. (2014). Introducing the short dark triad (SD3): A brief measure of dark personality traits. Assessment, 21, 28-41.

Kantanis, T. (2000). The role of social transition in students' adjustment to the firstyear of university. Journal of Institutional Research, 9, 100-110.

Karaca, N. H., Gündüz, A. ve Aral, N. (2011). Okul öncesi dönem çocuklarının sosyal davranışının incelenmesi. Kuramsal Eğitimbilim Dergisi, 4(2), 65-76.

Kerig, P. K., and Stellwagen, K. K. (2010). Roles of callous-unemotional traits, narcissism, and machiavellianism in childhood aggression. Journal of Psychopathological Behavior Assessment, 32, 343-352.

Kındap-Tepe, Y. ve Sayıl, M. (2012). Ebeveyn kontrolü ve ergenin sosyal işlevselliği arasındaki bağlantıda ilişkisel saldırganlığın aracı rolü. Türk Psikoloji Dergisi, 27(70), 119-132. 
Knight, N. M., Dahlen, E. R., Bullock-Yowell, E., Michael, B., and Madson, M. B. (2018). The HEXACO model of personality and dark triad in relational aggression. Personality and Individual Differences, 122, 109-114.

Kurtyılmaz, Y. (2011). Üniversite öğrencilerinin ilişkisel saldırganlık ile benlik saygısı, sosyal bağlılık ve sosyal kaygl düzeyleri arasındaki ilişkiler (Yayımlanmamış doktora tezi). https://tez.yok.gov.tr/UlusalTezMerkezi/'nden erişilmiştir (Tez No. 286823).

Kurtyılmaz, Y., Can, G. ve Ceyhan, A. A. (2017). Üniversite öğrencilerinin ilişkisel saldırganlık ile benlik saygısı, sosyal bağlılık ve sosyal kaygı düzeyleri arasındaki ilişkiler. Türk Psikolojik Danışma ve Rehberlik Dergisi, 7(47), 33-52.

Kurtyılmaz, Y., Can, G. ve Ceyhan, A. A. (2011, Ekim). Üniversite öğrencilerinin arkadaşlık ilişkilerinde ilişkisel saldırganlı̆̆ın dĕgerlendirilmesine ilişkin bir ölçek gelişstirme çalışması. XI. Ulusal Psikolojik Danışma ve Rehberlik Kongresi, İzmir.

LaFontana, K. M., and Cillessen, A. H. N. (2002). Children's perceptions of popular and unpopular peers: A multimethod assessment. Developmental Psychology, $38,635-647$.

Leary, M. R., Twenge, J. M., and Quinlivan, E. (2006). Interpersonal rejection as a determinant of anger and aggression. Personality and Social Psychology Review, $10,111-132$.

Lehmann, A., and Ittel, A. (2012). Aggressive behavior and measurement of psychopathy in female inmates of German prisons: A preliminary study. International Journal of Law and Psychiatry, 35(3), 190-197.

Linder, J. R., Crick, N. R., and Collins, W. A. (2002). Relational aggression and victimization in young adults' romantic relationships: Associations with perceptions of parent, peer, and romantic relationship quality. Social Development, 11(1), 69-86.

Loudin, J. L., Loukas, A., and Robinson, S. (2003). Relational aggression in college students: Examining the roles of social anxiety and empathy. Aggressive Behavior, 29(5), 430-439.

Loukas, A., Paulos, S. K., and Robinson, S. (2005). Early adolescent social and overt aggression: Examining the roles of social anxiety and maternal psychological control. Journal of Youth and Adolescence, 34, 335-345.

Lyons, M. T., and Hughes, S. (2015). Malicious mouths? The dark triad and motivations for gossip. Personality and Individual Differences, 78, 1-4.

Martin, R. A., Lastuk, J. M., Jeffery, J., Vernon, P. A., and Veselka, L. (2012). Relationship between the Dark Triad and humor styles: A replication and extension. Personality and Individual Differences, 52, 178-182. 
Masui, K., Fujiwara, H., and Ura, M. (2013). Social exclusion mediates the relationship between psychopathy and aggressive humor style in noninstitutionalized young adults. Personality and Individual Differences, 55(2), 180-184

Masui, K., Iriguchi, S., Terada, M., Nomura, M., and Ura, M. (2012). Lack of family support and psychopathy facilitates antisocial punishment behavior in college students. Psychology, 3, 284-288.

Marsee, M. A., Silverthorn, P., and Frick, P. J. (2005). The association of psychopathic traits with aggression and delinquency in non-referred boys and girls. Behavioral Sciences \& the Law, 23(6), 803-817.

McAndrew, F. T., and Milenkovic, M. A. (2002). Of Tabloids and family secrets: The evolutionary psychology of gossip. Journal of Applied Social Psychology, 32(5), 1064-1082.

Mills, C. (2010). Experiencing gossip: The foundations for a theory of embedded organizational gossip. Group \& Organization Management, 35(2), 213-240.

Moss, B. F., and Schwebel, A. I. (1993). Defining intimacy in romantic relationships. Family Relations, 42(1), 3-37.

Newcomb, A. F., and Bagwell, C. L. (1995). Children's friendship relations: A metaanalytic review. Psychological Bulletin, 117(2), 306-347.

Newman, J. P., MacCoon, D. G., Vaughn, L. J., and Sadeh, N. (2005). Validating a distinction between primary and secondary psychopathy with measures of Gray's BIS and BAS constructs. Journal of Abnormal Psychology, 114, 319 323.

O’boyle, E. H., Forsyth, D. R., Banks, G. C., and Mcdaniel, M. A. (2012). A metaanalysis of the dark triad and work behavior: A social exchange perspective. Journal of Applied Psychology, 97(3), 557-579.

Özsoy, E. ve Ardıç, K. (2017). Karanlık Üçlü’nün (Narsisizm, Makyavelizm ve psikopati) iş tatminine etkisinin incelenmesi. Yönetim ve Ekonomi, 24(2), 391406.

Özsoy, E., Rauthmann, J. F., Jonason, P. K., and Ardıç, K. (2011). Reliability and validity of the Turkish versions of dark triad dirty dozen (DTDD-T), short dark triad (SD3-T), and single item narcissism scale (SINS-T). Personality and Individual Differences, 117, 11-14.

Paal, T., and Bereczkei, T. (2007). Adult theory of mind, cooperation, Machiavellianism: The effect of mindreading on social relations. Personality and Individual Differences, 43(3), 541-551. 
Paulhus, D. L., and Williams, K. M. (2002). The dark triad of personality: Narcissism, machiavellianism, and psychopathy. Journal of Research in Personality, 36, 556-563.

Peeters, M., Cillessen, A. H. N., and Scholte, R. H. J. (2010). Clueless or powerful? Identifying subtypes of bullies in adolescents. Journal of Youth and Adolescents, 39, 1041-1052.

Pittman, L. D., and Richmond, A. (2008). University belonging, friendship quality and psychological adjustment during the transition to college. The Journal of Experimental Education, 76(4), 343-361.

Polatcı, S., Irk E., Gültekin, Z. ve Sobacı, F. (2017). Psikolojik dayanıklılık ve kişilik özellikleri tatmin düzeyini etkiler mi? Süleyman Demirel Üniversitesi Sosyal Bilimler Enstitüsü Dergisi, 29, 553-578.

Pursoo, T. (2013). Predicting reactive and proactive relational aggression in early adolescence as a function of individual differences in Machiavellianism, empathy, and emotion regulation (Unpublished doctoral dissertation). https://ruor.uottawa.ca/handle/10393/26119 adresinden erişilmiştir.

Rose, P. (2002). The happy and unhappy faces of narcissism. Personality and Individual Differences, 33(3), 379-391.

Schmeelk, K. M., Sylvers, P., and Lilienfeld, S. O. (2008). Trait correlates of relational aggression in a nonclinical sample: DSM-IV personality disorders and psychopathy. Journal of Personality Disorders, 22(3), 269-283.

Sevinç-Tuhanioğlu, S. (2017). Üniversite birinci sınıf öğrencilerinin üniversite yaşamlarına uyumlarına katkı sağlayan bireysel ve çevresel faktörlerin incelenmesi (Yayınlanmamış doktora tezi). https://tez.yok.gov.tr/UlusalTez Merkezi/'nden erişilmiştir (Tez No. 454770).

Solmaz, B. (2006). Söylenti ve dedikodu yönetimi. Selçuk Üniversitesi Sosyal Bilimler Enstitüsü Dergisi, 16, 563-574.

Sumner, F. C. (1942). H. Cleckley: The mask of sanity. The Journal of General Psychology, 27(2), 367-368.

Sutton, J., and Keogh, E. (2000). Social competition in school: Relationships with bullying, Machiavellianism and personality. British Journal of Educational Psychology, 70, 443-456.

Toplu-Yaşlıoğlu, D. ve Atılgan, Ö. (2018). Karanlık üçlü ölçeği: Türkçeye uyarlama, güvenilirlik ve geçerlilik çalışması. Mehmet Akif Ersoy Üniversitesi İktisadi ve Ídari Bilimler Fakültesi Dergisi, 5(3), 725-739.

Underwood, M. K., Galen, B. R., and Paquette, J. A. (2001). Top ten challenges for understanding gender and aggression in children: Why can't we all just get along? Social Development, 10, 248-266. 
Uysal, H. ve Dinçer, Ç. (2013). Okul öncesi dönemde karşılaşılan fiziksel ve ilişkisel saldırganlığın bazı değişkenler açısından incelenmesi. Eğitim ve Bilim, 38(169), 328-345.

Warburton, W. A., Williams, K. D., and Cairns, D. R. (2006). When ostracism leads to aggression: The moderating effects of control deprivation. Journal of Experimental Social Psychology, 42(2), 213-220.

Warren, G. C., and Clarbour, J. (2009). Relationship between psychopathy and indirect aggression use in a noncriminal population. Aggressive Behavior, 35(5), 408-421.

Wastell, C., and Booth, A. (2003). Machiavellianism: An alexithymic perspective. Journal of Social and Clinical Psychology, 22(6), 730-744.

Wert, S. R., and Salovey, P. (2004). A social comparison account of gossip. Review of General Psychology, 8(2), 122-137.

Wilkinson, T. M. (2012). Nudging and manipulation. Political Studies, 61(2), 341355.

Williams, K. D. (2009). Ostracism: A temporal need-threat model. Advances in Experimental Social Psychology, 41, 275-314.

Wu, X., Kwan, H. K., Wu, L. Z., and Ma, J. (2018). The effect of workplace negative gossip on employee proactive behavior in China: The moderating role of traditionality. Journal of Business Ethics, 148(4), 801-815.

Young, S., and Pinsky, D. (2006). Narcissism and celebrity. Journal of Research in Personality, 40(5), 463-471. 


\title{
Relational Aggression Among University Students: The Role of Dark Triad Traits ${ }^{1}$
}

\begin{tabular}{cccc}
\hline ARTICLE TYPE & Received Date & Accepted Date & Published Date \\
Research Article & 02.03 .2020 & 02.06 .2021 & 04.19 .2021 \\
\hline \multicolumn{4}{c}{ Nesrin Karaaslan (iD) } \\
Ministry of National Education \\
Cem Ali Gizir (iD) \\
Mersin University
\end{tabular}

\begin{abstract}
The aim of this research is to examine the extent to which the Dark Triad (Machiavellianism, narcissism and psychopathy) personality traits predicted the relational aggression levels of university students. The sample of the study comprised of 725 (457 female, 268 male) undergraduate students from diverse faculties of a state university in Turkey during the 20182019 academic year. "Personal Information Form", "Relational Aggression Scale in Friendship Relations" and "Short Dark Triad Scale" were used in the study. Pearson correlation and multiple regression analysis were also used to analyze the data. The findings of the study indicated that Machiavellianism and psychopathy significantly predicted the relational aggression levels of university students. Similarly, it is observed that both Machiavellianism and psychopathy are significant predictors of the exclusion factor of relational aggression among university students. The results also revealed that only Machiavellianism predicted the manipulation factor of relational aggression while psychopathy predicted alone the gossip factor of relational aggression among university students. Nevertheless, narcissism did not seem to be a significant predictor of relational aggression levels of university students. The implications of this research were considered and some recommendations were made for practice.
\end{abstract}

Keywords: relational aggression, dark triad, Machiavellianism, narcissism, psychopathy, university students.

The Ethical Committee Approval: Since this research was conducted before 01.01.2020, it does not require an ethics committee decision.

\footnotetext{
${ }^{1}$ This research is an excerpt from the master's thesis of the first author supervised by the second author. ${ }^{2}$ School Counselor, Ministry of National Education, e-mail: nesrin-karaaslan2015@hotmail.com, https://orcid.org/0000-0002-3896-9699

${ }^{3}$ Corresponding Author: Prof., Faculty of Education, Department of Educational Sciences, e-mail: cagizir@mersin.edu.tr, https://orcid.org/ 0000-0002-1928-781X
} 


\section{Purpose and Significance}

One of the basic needs of individuals is belonging to a particular social environment in order to survive. Individuals need others to be listened and understood, to express themselves and to share their feelings. Specifically, the friendship relations provide individuals a wide variety of gains such as a sense of self, self-confidence, authenticity, belongingness, and social support etc. (Demir, Görgün-Baran, and Ulusoy, 2005). Thus, each individual has to adapt to various social groups in his or her environment. However, the attitudes and behaviors of the others in the group are of great importance for a healthy adaptation. Although individuals display mostly positive attitudes in their social relationships, they may sometimes have negative attitudes and behaviors towards others within social groups. Some of these negative behaviors are described as relational aggression involve gossiping and rumoring about others, excluding others and manipulation.

The Dark Triad personality traits are considered as one of the factors related to relational aggression (Abell and Brewer, 2014; Jones and Neria, 2015; Knight et al., 2018). These three traits including Machiavellianism, subclinical narcissism and subclinical psychopathy are shown as personality characteristics that enable individuals to use social relations for their own benefits and prevent establishing and/or maintaining healthy relationships in a social environment (Paulhus ve Williams, 2002). Although they contain diverse features from each other, these three personality traits, which are brought together under a single common concept, have some common aspects including, being selfish, establishing superficial relationships, and exhibiting manipulative and goal oriented behaviors in social relationships (Özsoy and Ardıç, 2017).

Although it is stated that friendship relations established through university years have contributed positively to the cognitive, social and emotional development of young-adults (Astin, 1993), relational aggression is indicated as one of the main factor negatively affecting close relationships during university years (Grotpeter and Crick, 1996; Kurtyllmaz, Can, and Ceyhan, 2017). On the other hand, there is no study encountered focusing on the relationship between the relational aggression and the Dark Triad personality traits among university students. Within this context, the aim of this study is to examine the extent to which the Dark Triad (Machiavellianism, narcissism and psychopathy) personality traits predicted the relational aggression (exclusion, manipulation, and gossiping) levels of university students.

\section{Method}

The sample of the study comprised of 725 (457 female, 268 male) undergraduate students from diverse faculties of a Turkish public university during the 2018-2019 academic year. The age of the participants ranged from 18 to 27 years with a mean of 21.44 years $(\mathrm{SD}=1.82)$. For grade level, $22.8 \%$ were first-year, $25.8 \%$ were sophomore, $30.1 \%$ were junior and $21.4 \%$ were senior university students. Since this 
research was conducted before 01.01 .2020 , it does not require an ethics committee decision.

"Personal Information Form (PIF)", "Relational Aggression Scale in Friendship Relations (RASFR)" and "Short Dark Triad Scale (SD3)" were used in the study. The $P I F$ was settled by researchers to collect background information about the participants such as their gender, age and grade. The RASFR is a 5-point Likert type self-report scale including 22 items and 3 factors namely, exclusion, manipulation, and gossiping (Kurtyllmaz, Can, and Ceyhan, 2011). The reported reliability of the scale estimated by Cronbach's alpha was .91 and test-retest reliability was .93 . The 27-item SD3 is also a 5-point Likert type self-report scale measures Machiavellianism, subclinical narcissism, and subclinical psychopathy (Jones and Paulhus, 2014). The SD3 is adapted to Turkish by Özsoy, Rauthmann, Jonason, and Ardıç (2017) and the internal reliability coefficients of the factors were reported as .71 for Machiavellianism, .79 for narcissism, and .77 for psychopathy.

Pearson correlation and multiple regression analysis were used to analyze the data. There are four multiple regression analyses performed using relational aggression and its three factors (exclusion, manipulation, and gossiping) separately, as dependent variables and three Dark Triad factors (Machiavellianism, narcissism, and psychopathy) as predictor variables. An alpha level of .05 was also used as a significance in the analyses.

\section{Results}

The results of the correlational analyses exhibited that there were significant positive zero-order correlations between Dark Triad personality traits and relational aggression factors. Multiple regression analysis indicated that Dark Triad dimensions of psychopathy $(\beta=.23, \mathrm{t}=5.84, \mathrm{p}<.01)$ and Machiavellianism $(\beta=.14, \mathrm{t}=3.50, \mathrm{p}<$ $.01)$ explained $11 \%$ of relational aggression variance $(F(3,721)=30.77, \mathrm{p}<.01)$. Again, both Machiavellianism and psychopathy explained $13 \%$ of the variance of exclusion factor of relational aggression $(F(3,721)=36.50, \mathrm{p}<.01)$. On the other hand, Machiavellianism $(\beta=.14 ; \mathrm{t}=3.47, \mathrm{p}<.01)$ was the only significant predictor and explained $4 \%$ of variance of manipulation factor $(\mathrm{F}(3,721)=8.47, \mathrm{p}<.01)$, while psychopathy $(\beta=.29 ; \mathrm{t}=7.38, \mathrm{p}<.01)$ seemed to be explained $10 \%$ of variance of gossiping, only $(\mathrm{F}(3,721)=26.40, \mathrm{p}<.01)$. However, the narcissism dimension of Dark Triad had no any significant contribution in explaining relational aggression and its factors.

\section{Discussion and Conclusions}

The findings of the study indicated that Machiavellianism and psychopathy significantly predicted the relational aggression levels of university students in their friendships. This finding is consistent with the previous research (Abell and Brewer, 2014; Banks, Forsyth, O'Boyle, and Story, 2013; Coyne and Thomas, 2008; Jones and Neria, 2015; Kerig and Stellwagen, 2010; Peeters, Cillessen, and Scholte, 2010). According to Warren and Clarbour (2009), psychopaths with low empathic tendencies 
display more relational aggression behavior in their relationships in order to control others due to the lack of emotional skills. Moreover, it is stated that relational aggression behaviors which are not directly displayed in the relationships such as using others for their own purposes, gossiping, exclusion from the group, using others with the threat of rumors might be reasonable for Machiavellians (Loukas, Paulos, and Robinson, 2005) within the framework of their negative world perception (Jones and Neria, 2015).

Similarly, it is observed that both Machiavellianism and psychopathy are significant predictors of the exclusion factor of relational aggression among university students. This finding is also consistent with the previous research (Erdoğan, 2018; Masui, Fujiwara, and Ura, 2013; Masui, Iriguchi, Terada, Nomura, and Ura, 2012; Leary, Twenge, and Quinlivan, 2006; O'boyle, Forsyth, Banks, and Mcdaniel, 2012; Peeters, Cillessen, and Scholte, 2010; Warburton, Williams, and Cairns, 2006). Herein Masui et al. (2013) specified that psychopathic individuals with negative temperament styles including, ignoring existing problems, disdaining or disregarding someone (Martin, Lastuk, Jeffery, Vernon, and Veselka, 2012) might have a tendency to exclude others in their social relationships. In addition, it is declared that Machiavellian individuals can resort to exclusion behavior in the face of all kinds of negativity that may come to their sense of belongingness (Abrams, Hogg, and Marques, 2004).

The result of the present study also revealed that only Machiavelism is the only Dark Triad characteristic that predicts the manipulation levels of university students in their friendship relations. This finding of the study seemed to be similar to the findings (Abell and Brewer, 2014; Abell, Brewer, Qualter, and Austin, 2016; Austin, Farrelly, Black, and Moore, 2007) in the literature. Actually, Machiavellian individuals believe that others are naive and inexperienced and can be easily deceived, so they do not have to worry about directing others for their own purposes (TopluYaşlıoğlu and Atilgan, 2018). It is also emphasized that Machiavellian individuals understand the feelings of others quite well, but they often use their traits to manipulate others.

In this study, it is also observed that the Dark triad characteristic of psychopathy predicted alone the gossiping factor of relational aggression among university students. This finding appeared to be similar to the results of a single study (Lyons and Hughes, 2015) emphasizes that individuals with psychopathic tendencies often apply to gossip about other individuals they do not like. Essentially, it seems quite probable that individuals with high psychopathic tendencies characterized by excessive impulsivity, lack of empathy and self-control behaviors (Paulhus and Williams, 2002), might try to harm others by gossiping in friendship relationships to achieve their personal goals.

On the other hand, narcissism did not seem to be a significant predictor of relational aggression and its factors (exclusion, manipulation, and gossiping) among university students. At this point, Coyne and Thomas (2008) stated that narcissism 
may not be associated with aggression, and narcissistic individuals do not engage in aggressive behavior unless they encountered ego threats and/or are provoked. Actually, it is very important for narcissistic individuals to be appreciated by others in their social milieu and they inevitably try to behave others in a more socially desirable manner (Campbell and Campbell, 2009).

Consequently, it seems clear that Dark Triad personality characteristics of Machiavellianism and psychopathy are important predictors of relational aggression factors in several ways. From this perspective, it is important to implement developmental and preventive programs through university counseling centers to minimize relational aggression behaviors among university students.

\section{The Ethical Committee Approval}

Since this research was conducted before 01.01.2020, it does not require an ethics committee decision. 